\title{
PENGARUH KUALITAS KEHIDUPAN KERJA TERHADAP KOMITMEN ORGANISASI
}

\author{
M. Isa Anshori \\ Fakultas Ekonomi Universitas Trunojoyo \\ Jl. Raya Telang, Kecamatan Kamal, Kabupaten Bangkalan, Madura \\ 16912 \\ E-mail: isa_feutm@yahoo.com
}

\begin{abstract}
Abstrac
Quality of work life is a level where members of an organization is able to satisfy important personal needs through his experience in doing the job in the organization. As well as the high commitment of the employees at the organization's employees will exert all their ability to perform all tasks assigned to them, including obey all the rules. Based on the comparison of t-values calculated by t-table where the $t$-calculated value was greater than the value of $t$-table then $\mathrm{H} 0$ refused and $\mathrm{H} 1$ accepted, meaning that independent variable compensation, job design, participation and job security partially have a significant effect on Insurance employees' organizational commitment "X" in Surabaya
\end{abstract}

Key word: Kualitas Kehidupan Kerja dan Komitmen Organisasi

Memasuki era globalisasi dan pasar bebas saat ini, persaingan terjadi di segala bidang kegiatan bisnis. Dalam menghadapi kompetisi pasar global maka dunia bisnis dan industri harus berbenah diri agar tetap eksis. Perusahaan merupakan salah satu bagian dalam mata rantai bisnis yang penting. Perusahaan tidak lagi bersaing secara nasional tetapi sudah harus mampu bersaing secara internasional sesuai dengan tuntutan global saat ini. Untuk mempertahankan kelangsungan hidupnya, perusahaan 
harus dapat menyesuaikan diri terhadap perubahan-perubahan yang terjadi baik di dalam maupun di luar perusahaan serta melakukan inovasi untuk mengembangkan perusahaan. Perusahaan perlu mengupayakan agar setiap sumber daya yang dimiliki dapat digunakan secara efektif dan efisien sehingga pada akhirnya perusahaan akan mendapatkan skala ekonomis dan meningkatkan kemampuan kompetitif perusahaan.

Salah satu sumber daya yang terpenting di dalam perusahaan adalah sumber daya manusia atau tenaga kerja. Sumber daya manusia merupakan elemen terpenting dalam mengoperasikan seluruh sumber daya lain yang terdapat di dalam perusahaan. Perusahaan perlu mengembangkan cara-cara baru untuk mengelola sumber daya manusia untuk dapat dimanfaatkan dalam usaha meningkatkan kemajuan perusahaan. Salah satu cara yang dapat diterapkan adalah dengan meningkatkan kualitas kehidupan kerja para karyawannya.

Kualitas kehidupan kerja merupakan suatu tingkat dimana anggota dari suatu organisasi mampu memuaskan kebutuhan pribadi yang penting melalui pengalamannya dalam melakukan pekerjaan pada organisasi tersebut. Kualitas kehidupan kerja ditentukan dari persepsi karyawan terhadap keadaan, mental dan fisik pada saat bekerja. Peningkatan kualitas kehidupan kerja akan membawa pengaruh yang positif terhadap organisasi. Pengaruh positif secara langsung yang diperoleh adalah pertama, meningkatkan kepuasan kerja dan komitmen terhadap organisasi/perusahaan diantara karyawan. Kedua, meningkatkan produktivitas. Ketiga, berkaitan dengan dua keuntungan sebelumnya, adalah meningkatkan efektivitas organisasi.

Disain perbaikan kualitas kehidupan kerja bermanfaat bagi karyawan dengan membuat suatu pekerjaan menjadi pengalaman yang memuaskan bagi karyawan, bagi perusahaan dengan mengurangi tingkat 
absensi dan turnover karyawan dan bagi konsumen melalui perbaikanperbaikan dalam menghasilkan produk. Perusahaan yang tidak memperhatikan faktor-faktor kualitas kehidupan kerja seperti rendahnya kompensasi, partisipasi karyawan, kondisi kerja dan desain pekerjaan dapat membuat karyawan kurang produktif serta rendahnya komitmen terhadap perusahaan.

Komitmen karyawan pada organisasi mempengaruhi karyawan tersebut untuk berusaha lebih baik dalam bekerja baik secara langsung maupun tidak langsung akan meningkatkan kinerja karyawan tersebut. Dengan adanya komitmen yang tinggi dari karyawan pada organisasi maka karyawan akan mengerahkan segala kemampuan mereka untuk melaksanakan segala tugas yang dibebankan kepada mereka termasuk menuruti segala peraturan yang ada. Karyawan memiliki kemampuan untuk mengkomitmenkan atau tidak mengkomitmenkan dirinya pada suatu organisasi. Setiap karyawan dituntut untuk selalu berkomitmen terhadap organisasi. Komitmen karyawan pada organisasi mencerminkan kepercayaan karyawan pada misi dan tujuan organisasi.

PT Asuransi " X " di Surabaya merupakan perusahaan yang bergerak dalam bidang jasa keuangan non bank dan merupakan perusahaan jasa asuransi yang beroperasi di Indonesia. Perusahaan ini menggunakan produk link yang bekerjasama dengan salah satu bank pemerintah yang relatif maju untuk melakukan kegiatan produksinya serta memiliki sumber daya manusia yang banyak serta beragam untuk menunjang kegiatan operasionalnya. Penelitian ini dikonsentrasikan untuk mengetahui faktor-faktor kualitas kehidupan kerja apa saja yang mempengaruhi komitmen organisasi karyawan.

Berdasarkan kerangka pemikiran yang dikemukakan di atas maka tujuan penelitian yang ingin dicapai adalah sebagai berikut: (1) Untuk 
mengetahui apa ada pengaruh yang bermakna dari faktor-faktor kualitas kehidupan kerja meliputi kompensasi, desain pekerjaan, partisipasi dan keamanan kerja secara bersama-sama terhadap komitmen organisasi. (2) Untuk mengetahui apa ada pengaruh faktor-faktor kualitas kehidupan kerja meliputi kompensasi, desain pekerjaan, partisipasi dan keamanan kerja secara parsial terhadap komitmen organisasi. (3) Untuk mengetahui faktor kualitas kehidupan kerja mana yang dominan berpengaruh terhadap komitmen organisasi.

Kualitas kehidupan kerja adalah suatu keadaan lingkungan kerja yang baik atau tidak baik bagi pekerja. Kegunaan yang mendasar adalah mengembangkan suatu lingkungan kerja yang baik yang sesuai dengan kesejahteraan ekonomi organisasi (Davis dan Newstrom, 1993). Mondy dan Noe (1993) berpendapat, kualitas kehidupan kerja adalah tingkat dimana anggota dari suatu organisasi kerja mampu memuaskan kebutuhan pribadi yang penting melalui pengalaman organisasi mereka. Sedangkan Cascio (1995) menyatakan bahwa kulitas kehidupan kerja ditentukan dari persepsi karyawan terhadap keadaan mental dan fisik pada saat bekerja. Mejia, Balkin dan Cardy (2001) menyatakan bahwa kualitas kehidupan kerja adalah suatu ukuran keamanan dan kepuasan yang dirasakan pekerja dalam melakukan pekerjaannya. Dari berbagai definisi di atas dapat diambil kesimpulan bahwa kualitas kehidupan kerja merupakan suatu tingkat dimana anggota dari suatu organisasi mampu memuaskan kebutuhan pribadi yang penting melalui pengalamannya dalam melakukan pekerjaan pada organisasi tersebut. Menurut Riggio (2000) yang mengutip pernyataan Efraty dan Sirgy menyatakan bahwa bukti mengindikasikan bahwa peningkatan kualitas kehidupan kerja akan membawa pengaruh yang positif terhadap organisasi seperti 
meningkatkan produktivitas dan kualitas dan menurunkan tingkat absensi dan perputaran karyawan.

Desain perbaikan kualitas kehidupan kerja bermanfaat bagi karyawan dengan membuat suatu pekerjaan menjadi pengalaman yang memuaskan bagi karyawan, bagi perusahaan dengan mengurangi tingkat absensi dan turnover karyawan dan bermanfaat bagi konsumen melalui perbaikan-perbaikan dalam menghasilkan produk. Hal ini sesuai dengan pendapat Bluestone dalam Miner dan Crane (1995)

Menurut Wether dan Davis (1993) kualitas kehidupan kerja dipengaruhi oleh beberapa faktor yaitu supervisi, kondisi kerja, gaji, tunjangan dan desain pekerjaan. Riggio (2000) menyatakan, bahwa kualitas kehidupan kerja ditentukan oleh kompensasi yang diterima karyawan, kesempatan untuk berpartisipasi dalam organisasi, keamanan kerja, desain pekerjaan dan kualitas interaksi antar anggota organisasi. Faktor-faktor yang mempengaruhi kualitas kehidupan kerja pada penelitian ini akan dibatasi menjadi empat faktor yang meliputi kompensasi, desain pekerjaan, partisipasi dan keamanan kerja.

Kompensasi adalah apa yang karyawan terima sebagai balasan dari kontribusinya terhadap organisasi (Werther dan Davis,1993). Sedangkan menurut Nitisemito (2000) bahwa kompensasi adalah balas jasa yang diberikan oleh perusahaan kepada karyawan, yang dapat dinilai dengan uang dan cenderung diberikan secara tetap. Kompensasi merupakan hal penting bagi karyawan karena akan mempengaruhi sikap dan perilaku kerja karyawan dalam suatu perusahaan sehingga setiap perusahaan perlu menetapkan kompensasi yang paling tepat agar dapat mendukung tercapainya tujuan perusahaan. Terdapat beberapa pertimbangan yang diperlukan dalam menetapkan kompensasi yang tepat menurut pendapat Nitisemito (2000) yaitu kompensasi harus dapat 
memenuhi kebutuhan minimal, kompensasi harus dapat mengikat, kompensasi harus dapat menimbulkan semangat dan kegairahan kerja, kompensasi harus adil, kompensasi tidak boleh bersifat statis, komposisi dari kompensasi yang diberikan harus diperhatikan.

Desain pekerjaan adalah fungsi penetapan kegiatan-kegiatan kerja seorang individu atau kelompok karyawan secara organisasional. Tujuannya adalah untuk mengatur penugasan-penugasan kerja yang memenuhi kebutuhan-kebutuhan organisasi, teknologi dan keperilakuan. Dari sudut pandangan manajemen personalia, desain pekerjaan sangat mempengaruhi kualitas kehidupan kerja, dimana hal ini tercermin pada kepuasan individu para pemegang jabatan (Handoko, 1999). Para karyawan menghabiskan banyak waktunya pada sebuah pekerjaan dan merupakan hal yang penting untuk mendesain pekerjaan dengan baik sehingga karyawan tersebut menyenangi pekerjaan mereka. Handoko (1999) menyatakan terdapat beberapa elemen keperilakuan yang perlu dipertimbangkan dalam desain pekerjaan yaitu otonomi pekerjaan, variasi pekerjaan, identitas tugas dan umpan balik pekerjaan.

Partisipasi adalah keterlibatan mental dan emosional orang-orang dalam situasi kelompok yang mendorong mereka untuk memberikan kontribusi kepada tujuan kelompok dan berbagi tanggung jawab dalam pencapaian tujuan (Newstrom dan Davis, 1993). Menurut pengertian ini partisipasi mengandung tiga gagasan penting yaitu keterlibatan mental dan emosional, motivasi untuk memberikan kontribusi dan penerimaan tanggung jawab. Keterlibatan mental dan emosional yang lebih dari sekedar aktivitas fisik, keseluruhan pribadi seseorang terlibat, bukan hanya keterampilan saja. Keterlibatan ini bersifat psikologis daripada fisik. Seseorang yang berpartisipasi akan lebih terlibat egonya daripada hanya terlibat tugas. Partisipasi ini dapat dilakukan dengan melibatkan 
karyawan dan ide-idenya dalam perencanaan dan pengambilan keputusan. Motivasi karyawan untuk memberikan kontribusinya dapat dilihat dengan cara karyawan diberi kesempatan untuk menyalurkan inisiatif dan kreatifitasnya dalam mencapai tujuan perusahaan. Partisipasi mendorong karyawan untuk menerima tanggung jawab dalam aktivitas kelompok. Hal ini merupakan suatu proses sosial dimana karyawan terlibat egonya dalam perusahaan dan menginginkan keberhasilan atas usahanya. Pada saat karyawan mau menerima tanggung jawab atas aktivitas kelompok, mereka melihat adanya peluang untuk melakukan hal-hal yang mereka inginkan, yaitu merasa tanggung jawab untuk menyelesaikan pekerjaannya.

Keamanan kerja adalah bebas dari ancaman fisik maupun psikologis, meliputi keamanan pada saat karyawan bekerja dan rasa aman di masa depan. Bila keamanan kerja terjamin maka dapat mengurangi kegelisahan, meningkatkan semangat dan kegairahan kerja para karyawan. Keamanan pada saat karyawan bekerja biasanya berkaitan dengan program keamanan dan kesehatan karyawan yang pelaksanaannya diatur oleh pemerintah dan perusahaan wajib mematuhinya. Adanya program ini dimaksudkan untuk mengurangi terjadinya kecelakaan dan penyakit yang disebabkan oleh pekerjaan. Handoko (1999) menyatakan bahwa program-program keamanan dan kesehatan karyawan dapat dilakukan dalam berbagai bentuk yaitu membuat kondisi kerja aman seperti dengan membeli atau mempergunakan mesin-mesin yang dilengkapi alat-alat pengaman, melakukan kegiatan-kegiatan pencegahan kecelakaan seperti dengan memasang poster-poster untuk selalu mengingatkan tentang keamanan dan penciptaan lingkungan kerja yang sehat untuk menjaga kesehatan 
para karyawan dari gangguan-gangguan penglihatan, pendengaran, kelelahan dan lain-lain.

Komitmen pada organisasi meliputi tiga sikap: (1) perasaan identifikasi pada tujuan organisasi, (2) perasaaan keterlibatan dalam tugas organisasi dan (3) perasaan loyalitas atau kesetiaan terhadap perusahaan (Gibson, Ivancevich dan Donnelly, 1985). Dengan demikian orang yang berkomitmen pada organisasi tidak berkeinginan untuk berhenti bekerja dan menerima pekerjaan di organisasi lain. Steers dan Porter (1991) memberikan definisi komitmen pada organisasi sebagai kekuatan relatif identifikasi dan keterlibatan individu pada suatu organisasi tertentu yang diindikasikan dengan adanya keyakinan kuat pada tujuan dan nilai-nilai organisasi, kesediaan untuk melakukan usahausaha tertentu bagi kepentingan organisasi serta keinginan kuat untuk terus menjadi anggota organisasi. Definisi ini mengandung ide loyalitas organisasi atau perusahaan tetapi komitmen organisasi lebih luas dari sekedar loyalitas yang sifatnya pasif karena menuntut karyawan untuk memberi kontribusi aktif bagi organisasi. Lebih lanjut, Steers dan Porter (1991) mengatakan bahwa komitmen pada organisasi merupakan proses yang berkesinambungan di mana pelaku-pelaku organisasi memperlihatkan kepedulian mereka pada organisasi serta kelangsungan keberhasilan dan kebaikan organisasi.

Newstrom dan Davis (1993) mengemukakan bahwa komitmen organisasi merupakan tingkat dimana karyawan mengenal organisasi dan berkeinginan untuk terus berpartisipasi secara aktif dalam organisasi tersebut. Lebih lanjut Newstrom dan Davis (1993) mengemukakan komitmen organisasi merupakan ukuran kemauan karyawan untuk tinggal atau bertahan dalam perusahaan di masa depan. Komitmen organisasi juga mencerminkan kepercayaan karyawan pada misi dan 
tujuan perusahaan, kemauan untuk melakukan usaha-usaha tertentu dalam mencapai misi dan tujuan itu serta berniat untuk terus bekerja pada organisasi tersebut. Sementara itu Greenberg dan Baron (1993) mengemukakan bahwa komitmen organisasi, merefleksikan tingkat seseorang individu mengidentifikasi dan terlibat dengan organisasinya serta tidak berkeinginan untuk meninggalkan organisasi tersebut. Identifikasi pada organisasi diartikan sebagai kondisi saling membagi tujuan dari anggota-anggota organisasi, merasa memiliki organisasi dan adanya loyalitas pada organisasi. Sedangkan keterlibatan pada organisasi dipandang sebagai keinginan individu untuk terlibat secara aktif guna mencapai tujuan organisasi dan senantiasa mendukung tujuan tersebut. Dari beberapa definisi di atas dapat disimpulkan bahwa komitmen organisasi merupakan kekuatan relatif dari identifikasi dan keterlibatan individu dengan organisasi. Komitmen mengandung definisi loyalitas tetapi komitmen lebih dari sekedar loyalitas karena melibatkan hubungan aktif individu dengan organisasi dimana individu memberikan sesuatu dari dirinya untuk membantu organisasi mencapai sukses. Komitmen organisasi merupakan suatu proses yang berkelanjutan dimana seluruh pelaku yang berkaitan dengan organisasi mengekspresikan perhatiannya pada kepentingan organisasi.

Meyer dan kawan-kawan (1993) juga mengemukakan tiga bentuk komitmen yang digunakan dalam mendekati komitmen organisasi yaitu komitmen afektif, kontinuan dan normatif. Komitmen afektif, dipengaruhi atau berkembang apabila keterlibatan dalam organisasi terbukti menjadi pengalaman yang memuaskan yaitu dapat memberikan kesempatan untuk melakukan pekerjaan dengan memuaskan atau menghasilkan kesempatan untuk menghasilkan skill yang berharga. Greenberg dan Baron (1993) mengatakan bahwa komitmen afektif 
hampir sama dengan pendekatan orientasi kesamaan tujuan individual organisasional yang menunjukkan kuatnya keinginan seseorang untuk terus bekerja bagi organisasi karena ia sejalan dan memang berkeinginan untuk melakukannya. Komitmen kontinuan, dipengaruhi dan atau dikembangkan pada saat individu melakukan investasi yang mana investasi tersebut akan hilang atau berkurang nilainya apabila individu beralih dari organisasinya. Komitmen ini berhubungan dengan pendekatan side-bets atau pendekatan orientasi sisi pertaruhan yang menunjukkan kuatnya tendensi kebutuhan sesorang untuk terus bekerja bagi organisasi (Greenberg dan Baron, 1993). Komitmen normatif, dipengaruhi dan atau berkembang sebagai hasil dari internalisasi tekanan normatif untuk melakukan serangkaian tindakan tertentu dan penerimaan keuntungan yang menimbulkan perasaan akan kewajiban yang harus dibalas.

Karyawan dengan komitmen afektif yang kuat bertahan dalam organisasi karena mereka "menginginkan" (want to); karyawan dengan komitmen kontinuan yang kuat bertahan dalam organisasi karena mereka "membutuhkan" (need to); sedangkan karyawan dengan komitmen normatif yang kuat bertahan dalam organisasi karena mereka merasa "seharusnya" (ought to) berbuat hal tersebut. Menurut Greenberg dan Baron (1993) terdapat tiga keuntungan yang dapat diperoleh dari penerapan kualitas kehidupan kerja yaitu meningkatkan kepuasan kerja dan komitmen terhadap organisasi diantara karyawan, meningkatkan produktivitas dan meningkatkan efektivitas organisasi. Studi-studi telah menemukan bahwa tingkat komitmen organisasi yang tinggi cenderung dihubungkan dengan tingkat absensi dan turnover yang rendah. Sehingga semakin berkomitmen seseorang karyawan semakin berkurang 
keinginannya untuk mencari pekerjaan baru dibandingkan dengan mereka yang kurang berkomitmen (Roberts dan Hunt, 1991).

Miner (1992) menyatakan bahwa komitmen yang tinggi mempunyai hubungan yang positif dengan rendahnya absensi atau ketidakhadiran dan produktifitas yang tinggi. Karyawan yang benarbenar berkomitmen pada organisasi biasanya mempunyai catatan kehadiran yang baik, memiliki kesetiaan dan ketaatan pada kebijaksanaan perusahaan dan mempunyai tingkat turnover yang rendah (Newstrom dan Davis, 1993).

\section{METODE}

Penelitian ini merupakan penelitian observasional analitik dengan metode survey untuk mengetahui Pengaruh Kualitas Kehidupan Kerja Terhadap Komitment Organisasi. Subjek penelitian ini adalah karyawan PT Asuransi "X" di Surabaya. Objek penelitian adalah Pengaruh Kualitas Kehidupan Kerja Terhadap Komitmen Organisasi. Variabel penelitian yang akan diukur dalam penelitian ini berjumlah 5 (lima) variabel yang terdiri dari 1 (satu) variabel tergantung dan 4 (empat) variabel bebas. Variabel-variabel tersebut adalah : (1) Variabel tergantung (Y), yaitu komitmen organisasi. (2) Variabel bebas (X), yaitu faktor-faktor kualitas kehidupan kerja, meliputi : (a) Kompensasi $\left(\mathrm{X}_{1}\right)$. (b) Desain Pekerjaan $\left(X_{2}\right)$. (c) Partisipasi $\left(X_{3}\right)$, dan (d) Keamanan Kerja $\left(X_{4}\right)$

Dalam penelitian ini digunakan teknik Simple Random Sampling yaitu teknik pengambilan sampel yang dilakukan secara acak tanpa memperhatikan strata yang ada dalam populasi yang diteliti. Populasi karyawan PT. Asuransi " X " di Surabaya dengan jumlah karyawan sebesar 480 orang. Arikunto (1998) berpendapat bahwa "apabila jumlah subyeknya besar dapat diambil antara $10-15 \%$ atau $20-25 \%$ atau lebih" 
Dalam penelitian ini jumlah sampel yang diambil adalah sebesar $480 \mathrm{x}$ $10 \%=48$ orang. Perhitungan sampel tersebut didasarkan pada tingkat kesalahan 5\%. Jadi sampel yang diperoleh mempunyai tingkat kepercayaan $95 \%$ terhadap populasi.

Data yang diperoleh akan dianalisis dengan menggunakan teknik analisis statistik Multiple Regression Analysis (MRA). MRA adalah sebuah teknik analisis yang secara simultan membangun suatu hubungan matematis antara dua atau lebih variabel independen dan sebuah variabel dependen yang berskala interval. Uji $\mathrm{F}$ dilakukan untuk mengetahui signifikansi pengaruh variabel bebas secara bersama-sama. Uji $t$ dilakukan untuk mengetahui signifikansi pengaruh variabel bebas secara parsial terhadap variabel tergantung.

\section{HASIL DAN PEMBAHASAN}

Data yang berhasil dikumpulkan selanjutnya dianalisis dengan menggunakan metode kuantitatif, yaitu metode statistik dengan menggunakan metode regresi linier berganda. Dari hasil analisis tersebut diperoleh nilai-nilai yang disajikan pada tabel 1 .

\section{Tabel 1}

Hasil Analisis Regresi Linier Berganda

\begin{tabular}{|l|l|l|l|l|}
\hline \multicolumn{1}{|c|}{ Variabel } & $\begin{array}{c}\text { Koefisien } \\
\text { Regresi }\end{array}$ & $\mathrm{t}$ hitung & Sign & $\mathrm{R}$ parsial \\
\hline $\mathrm{X}_{1}$ (kompensasi) & 0,211 & 2,925 & 0,005 & 0,407 \\
$\mathrm{X}_{2}$ (desain & 0,218 & 2,779 & 0,008 & 0,390 \\
pekerjaan) & 0,157 & 2,389 & 0,021 & 0,342 \\
$\mathrm{X}_{3}$ (partisipasi) & 0,175 & 2,569 & 0,014 & 0,365 \\
$\mathrm{X}_{4}$ (keamanan & 0,915 & & & \\
\hline
\end{tabular}




\begin{tabular}{|l|l|l|l|}
\hline $\begin{array}{l}\text { kerja) } \\
\text { Konstanta }\end{array}$ & & & \\
\hline $\mathrm{R}=0,747$ & F hitung $=13,536$ & $\mathrm{~N}=48$ \\
$\mathrm{R}^{2}=0,557$ & Sign $=0,000$ & \\
\hline
\end{tabular}

Dari tabel 1 dapat diperoleh persamaan regresi linier berganda sebagai berikut :

$$
\mathrm{Y}=0,915+0,211 \mathrm{X}_{1}+0,218 \mathrm{X}_{2}+0,157 \mathrm{X}_{3}+0,175 \mathrm{X}_{4}+\mathrm{e}
$$

Koefisien regresi yang bertanda positif menunjukkan pengaruh yang searah antara $\mathrm{X}$ (faktor-faktor kualitas kehidupan kerja) dan $\mathrm{Y}$ (komitmen organisasi). Nilai koefisien korelasi berganda (R) dari persamaan regresi linier berganda di atas adalah sebesar 0,747 artinya terdapat hubungan yang kuat antara variabel bebas (X) dengan variabel tergantungya $(\mathrm{Y})$. Nilai koefisien determinasi $\left(\mathrm{R}^{2}\right)$ dari persamaan regresi linier berganda di atas adalah sebesar 0,557 berarti bahwa 55,7\% dari perubahan variabel komitmen organisasi $(\mathrm{Y})$ dipengaruhi oleh variabel $\mathrm{X}_{1}$ (kompensasi), $\mathrm{X}_{2}$ (desain pekerjaan), $\mathrm{X}_{3}$ (partisipasi) dan $\mathrm{X}_{4}$ (keamanan kerja), sedangkan 44,3\% dipengaruhi oleh faktor-faktor lain di luar empat variabel yang diamati. Koefisien determinasi $\left(\mathrm{R}^{2}\right)$ sebesar 0,557 dapat dikatakan tinggi seperti yang dinyatakan oleh Ritvield dan Lasmono (1994) bahwa "pada kasus penelitian sosial, $\mathrm{R}$ antara 0,4-0,6 dapat dikatakan tinggi”.,

Dari hasil uji F diketahui F-hitung sebesar 13,536 dengan tingkat signifikansi sebesar 0,000 . Sedangkan nilai F-tabel ditentukan berdasarkan tabel $\mathrm{F}$ dengan tingkat signifikansi $5 \%$ dan $\mathrm{V}_{1}=\mathrm{k}=4$ serta $\mathrm{V}_{2}=\mathrm{n}-\mathrm{k}-1=48-4-1=43$. Sehingga diperoleh nilai F-tabel sebesar 2,59. Karena nilai F-hitung > F-tabel maka $\mathrm{H}_{0}$ ditolak dan $\mathrm{H}_{1}$ diterima 
artinya variabel bebas yaitu kompensasi, desain pekerjaan, partisipasi dan keamanan kerja secara bersama-sama mempunyai pengaruh yang bermakna terhadap komitmen organisasi karyawan PT Asuransi "X" di Surabaya.

Pada uji $\mathrm{t}$, nilai $\mathrm{t}$-tabel ditentukan dengan melihat tabel $\mathrm{t}$ pada tingkat signifikansi sebesar $5 \%$ dan df $=\mathrm{n}-\mathrm{k}-1=48-4-1=43$, sehingga diperoleh nilai t-tabel sebesar 2,0167. Selanjutnya nilai t-tabel dibandingkan dengan t-hitung yang didapatkan dari tabel 1 dan didapatkan $\mathrm{t} \mathrm{X}_{1}, \mathrm{t} \mathrm{X}_{2}, \mathrm{t} \mathrm{X}_{3}, \mathrm{t} \mathrm{X}_{4}>\mathrm{t}$-tabel. Berdasarkan perbandingan nilai t-hitung dengan $t$-tabel dimana ternyata nilai t-hitung lebih besar dari nilai t-tabel maka $\mathrm{H}_{0}$ ditolak dan $\mathrm{H}_{1}$ diterima, artinya variabel bebas yaitu kompensasi, desain pekerjaan, partisipasi dan keamanan kerja secara parsial mempunyai pengaruh yang bermakna terhadap komitmen organisasi karyawan PT Asuransi "X" di Surabaya.

\section{KESIMPULAN}

Berdasarkan hasil analisis dan pembahasan, maka dapat disimpulkan bahwa nilai koefisien korelasi berganda (R) dari model persamaan regresi linier berganda adalah sebesar 0.747 yang menunjukkan hubungan yang kuat antara keempat variabel kualitas kehidupan kerja terhadap komitmen organisasi. Nilai koeefisien determinasi $\left(\mathrm{R}^{2}\right)$ adalah sebesar 0,557. Hal ini berarti bahwa 55,7 \% dari perubahan nilai komitmen organisasi $(\mathrm{Y})$ dipengaruhi oleh variabel $\mathrm{X}_{1}$ (kompensasi), $\mathrm{X}_{2}$ (desain pekerjaan), $\mathrm{X}_{3}$ (partisipasi) dan $\mathrm{X}_{4}$ (keamanan kerja), sedangkan 44,3\% dipengaruhi oleh faktor lain diluar empat variabel yang diamati.

Berdasarkan nilai F-hitung sebesar 13,536 yang lebih besar dari F-tabel sebesar 2,59, maka dapat dikatakan bahwa variabel $\mathrm{X}_{1}$ 
(kompensasi), $\mathrm{X}_{2}$ (desain pekerjaan), $\mathrm{X}_{3}$ (partisipasi) dan $\mathrm{X}_{4}$ (keamanan kerja) secara bersama-sama mempunyai pengaruh yang bermakna terhadap komitmen organisasi karyawan. Sementara itu hasil uji t, menunjukkan bahwa nilai t-hitung dari masing- masing variabel bebas yaitu : $\mathrm{t} \mathrm{X}_{1}=2,925, \mathrm{t} \mathrm{X}_{2}=2,779, \mathrm{t} \mathrm{X}_{3}=2,389$ dan $\mathrm{tX}_{4}=2,569$ lebih besar dari nilai t-tabel sebesar 2,0167 sehingga variabel bebas yang terdiri dari $\mathrm{X}_{1}$ (kompensasi), $\mathrm{X}_{2}$ (desain pekerjaan), $\mathrm{X}_{3}$ (partisipasi) dan $\mathrm{X}_{4}$ (keamanan kerja) secara parsial mempunyai pengaruh yang bermakna terhadap komitmen organisasi karyawan PT. Asuransi " X" di Surabaya. Koefisien korelasi parsial menunjukkan bahwa variabel $\mathrm{X}_{1}$ (kompensasi) memiliki nilai yang paling besar dibandingkan variabel bebas lainnya. Sehingga variabel $\mathrm{X}_{1}$ (kompensasi) merupakan variabel yang dominan berpengaruh terhadap komitmen organisasi karyawan PT. Asuransi " X" di Surabaya. 


\section{DAFTAR PUSTAKA}

Arikunto, M. Suharsimi. 1998. Prosedur Penelitian Suatu Pendekatan

Praktek, Jakarta: PT. Rineka Cipta.

Cascio, Wayne F. 1995. Managing Human Resource, Productivity, Quality of Work Life, Profits. Fourth Edition. New York: McGraw-Hill, Inc.

Greenberg, Gerald and Robert A. Baron. 1993. Behaviour in Organizations. Fourth Edition. Massachusetts: Simon and Schuster, Inc. Handoko, T. Hani. 1999. Manajemen Personalia dan Sumber Daya Manusia. Edisi Kedua. Yogyakarta: BPFE.

Gibson, James L., John M. Ivancevich, and James H. Donnely Jr.. 1985. Organization: Behaviour, Structure, Process. Texas: Business Publications, Inc.

Mejia, Luis R. Gomez, Davis B. Balkin, and Robert L. Cardy. 2001. Managing Human Resources. New Jersey: Prentice Hall, Inc.

Meyer, John P. Natalie J. Allen dan Carl A. Smith. 1993. Commitment to Organization and Occupation; Extention and Test a Three-Component Conceptualization. Journal applied Psychology, Vol 78, No.4, PP.538551.

Miner, John B. 1992. Industrial Organization Psychology, International Edition. New York: McGraw Hill, Inc.

Miner, John B. and Donald P. Crane. 1995. Human Resource Management, The Strategic Perspective. New York: Harper Collins College Publishers.

Mondy, R. Wayne and Robert M. Noe III. 1993. Human Resouce Management. Fifth Edition. Massachusetts: Simon and Schuster, Inc. 
Newstrom, John W. and Keith Davis. 1993. Organizational Behaviour : Human Behavior at Work. Ninth Edition. New York: McGraw Hill, Inc.

Nitisemito, Alex S. 2000. Manajemen Personalia (Manajemen Sumber Daya Manusia). Jakarta: Ghalia Indonesia.

Riggio, Ronald E. 2000. Introduction to Industrial/Organizational Psychology, Third Edition. New Jersey: Prentice Hall, Inc.

Robert, Karlene H. and David M. Hunt. 1991. Organizational and Behaviour. Boston: PWS-Kent Publishing Company

Steers, Richard M. and Lyman W. Porter (ed) 1991. Motivation and Work Behaviour. Fifth Edition. New York: Mc Graw Hill, Inc.

Sugiyono. 2002. Metode Penelitian Bisnis. Bandung: CV. Alfabeta.

Werther, William B. and Keith Davis. 1993. Human Resource and Personnel Management. Fourth Edition. Singapore: McGraw-Hill Book Co. 